\title{
Identification of As-bearing minerals associated with mine wastes from former metalliferous mines in France using laboratory reflectance spectra
}

\author{
V. Carrère \\ Laboratoire de Planétologie et Géodynamique, UMR CNRS 6112, \\ Université de Nantes, France
}

\begin{abstract}
Arsenopyrite-rich wastes from former metalliferous mines in the Massif Central Region, France, contribute, through intensive leaching, to the formation of thin layers of As-Fe crusts on the tailing surfaces acting as a cement. When subject to rainfall, acid mine drainage develops, As is remobilized and trapped secondarily by oxyhydroxides or sulphates such as goethite, hematite, jarosite, etc., depending on water $\mathrm{pH}$. The aim of this study is to assess the potential of hyperspectral remote sensing in this particular environment (small outcrops, important leaching process, vegetated environment). Samples were collected in the field from tailings and stream bottoms in various sites. Reflectance spectra of the samples were acquired in the laboratory using a field spectrometer under artificial illumination (0.4-2.5 $\mu \mathrm{m}$ spectral range). Mineral composition was estimated by comparing reflectance spectra to reference spectral libraries. This was done after continuum removal, using two different techniques, in order to minimize the influence of factors such as grain size or moisture content. Geochemical and SEM-EDS analyses were performed to gather information on the mineralogy. Preliminary results from spectral analyses show clear evidence of jarosite, goethite or limonite, schwertmannite and scheelite in various proportions, depending on crust types, confirmed by SEM-EDS analyses.

Keywords: surface spectral reflectance, mine wastes, continuum removal, iron oxyhydroxides.
\end{abstract}




\section{Introduction}

Mining activities generate a multiform pollution due to sulphides oxidation present in the tailings. Their contact with atmospheric conditions can lead to Acid Mine Drainage (AMD) (Johnson and Thornton [1]; Webster et al. [2]), a remobilisation of toxic elements $(\mathrm{As}, \mathrm{S}, \mathrm{Pb}, \ldots)$ which could be immobilized in the sediments, the soils, by a more or less stable trapping. Some of these elements can be temporarily fixed in different ways: precipitation as oxides, hydroxides or sulphates (Herbert [3]), and absorption onto different materials (Karathanasis and Thompson [4]). Due to its presence as a major element accompanying many types of ore deposits, As is present in numerous mining areas. Because of its toxicity, its solubility has been extensively studied (e.g. Azcue et al. [5]; Hunt and Howard [6]; Roussel et al. [7]). Richardson and Vaughan [8] studied the early stages of arsenopyrite oxidation using spectroscopic investigations. They showed that in conditions of low $\mathrm{pH}$, such as those found in tailings dumps, arsenopyrite oxidizes rapidly and forms highly soluble As compounds as well as Fe(II) or Fe(III) arsenites or arsenates. According to local chemical conditions, As, $\mathrm{Fe}$ and $\mathrm{S}$ may be exported in drainage waters (Nesbitt et al. [9]; Savage et al. [10]). These elements could precipitate as authigenic minerals (Scott [11]; Jambor [12]) or amorphous material or can be adsorbed onto Fe oxides, hydroxides, or suspended material (Pierce and Moore [13]; Tsung-Hui et al. [14]; Manning et al. [15]).

In the French Massif Central, mining activities were greatly developed in the twentieth century. Thus, before the 1980's abundant mining tailings were generated and laid in dumps without any remediation. The present study focuses on one site, the site of Enguialès, located in the Aveyron Department, France (Figure 1), which was slightly remediated. Courtin-Nomade et al. [16] provided a detailed description of mineralogical and geochemical conditions of the tailings which is used as a reference for analyzing the spectral information. As-rich Fe cements are well developed as weathering crusts within the dumps. The size of the site (roughly $1 \mathrm{~km}^{2}$ ) is well suited for estimating the efficiency of hyperspectral reflectance data, a non-destructive approach, to identify and map the various minerals that could potentially be used as markers for As contamination. Previous studies on other sites clearly showed (see for example Swayze et al. [17]) that hyperspectral reflectance data allow to identify mineral phases onto which As can be adsorbed (iron oxyhydroxides, clays) based on diagnostic absorption features. Moreover, mineral assemblages can be used as indicator of acidity or chemical conditions that can control As mobility in soils and rivers.

We present preliminary results on the potential of hyperspectral surface reflectance measurements to identify mineralogical phases susceptible to have high As concentration and/or mineral associations indicative of soil acidity in such a specific context. More classical approaches such as mineralogical, chemical and SEM-EDS analyses were also used to validate these identifications. 


\subsection{Site description}

This tungstiferous deposit is located in the "La Châtaigneraie" district, in the south of the French Massif Central (Figure 1). Mineralized veins are mainly composed of wolframite, scheelite, pyrite and arsenopyrite. The mining activities ceased in 1979. The tailings represent $300000 \mathrm{t}$ directly spread out in a steep slope $\left(\sim 35^{\circ}\right)$ on about $22000 \mathrm{~m}^{2}$. The tailings are disposed as a pile ravined by AMD and meteoric waters. The remediation that was done on this site consisted of closing galleries access and gathering all the waters in only one dewatering point, which induced AMD phenomenon. Currently only the meteoric waters circulate across the tailings. Nevertheless, the Eh-pH conditions are oxidant and always very acidic with $\mathrm{pH}=2.8+/-0.3$. The oxidation of the tailings is expressed by local iron oxyhydroxides crusts, especially well developed in the gullies. Grains of ore gangue (quartz, muscovite and tourmaline) mainly constitute these iron crusts. These primary minerals are bound by a Fe-As rich cement. The richest As product corresponds to an amorphous iron "arsenate" which is mainly observed in the ochre cement rather than in the red cement. In the current Eh-pH conditions in Enguialès, the estimated solubilities show a high potentiality to release As from the identified amorphous arsenate. On the contrary, the most crystallized products as goethite or jarosite, in which As is also trapped (Courtin-Nomade et al. [18]), appear as stable minerals in the long term (Stahl et al. [19]).

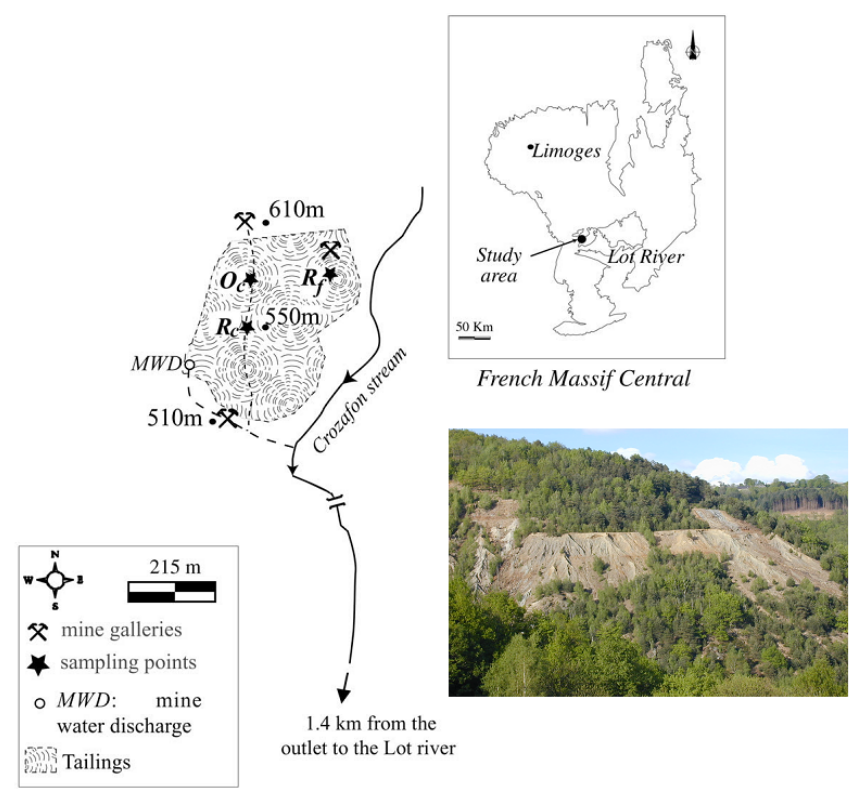

Figure 1: The Enguialès mine test site: General view and site location (after Courtin-Nomade et al. [16]). 


\subsection{Sample collection}

The various surface types that can be observed at the tailings surface were sampled in the field in December 2002. Only the surface was scraped in order to be representative of what can be observed by field or airborne hyperspectral instruments. Samples collection was based on surficial visual characteristics (color and aspect). When compared to descriptions published in the literature for this site (Courtin-Nomade et al. [16]; Courtin-Nomade et al. [18]), they could be attributed to 5 main categories: (1) micaschists (in place bedrock); (2) grey sand; (3) ochre cement; (4) red cement and (5) dark-reddish cement.

\section{Spectral analyses}

Spectral absorption features observed in the visible to short-wave infrared wavelength region result from several distinct processes. In the spectral range from 0.4 to $1.2 \mu \mathrm{m}$, absorption features are produced mainly by energy level changes in the valence of transition metals (crystal field transitions), by paired excitations of metal cations, or by charge transfer between metal cations and their associated ligands (Hunt and Ashley [20]; Sherman and Waite [21]; Burns [22]; Clark [23]). Absorption features in the SWIR region (1.3-2.5 $\mu \mathrm{m})$ are generated by molecular vibration processes: for example, the 1.4 and $1.9 \mu \mathrm{m}$ absorptions are related to the first overtones of the water $\mathrm{O}-\mathrm{H}$ stretching fundamentals and the combination water $\mathrm{O}-\mathrm{H}$ stretching with $\mathrm{H}-\mathrm{O}-\mathrm{H}$ bending vibrations, respectively (Hunt et al. [24]).

Laboratory spectral measurements in the VIS-SWIR spectral range of samples of the five surface types were recorded using a Spectralon TM white reference standard and an ASD FieldSpec FR spectrometer under artificial illumination. Figure 2 shows the resulting reflectance spectra. The five spectral signatures are rather different and show most of their distinctive absorption features in the visible-near infrared (VNIR). The drop-off toward the U.V. corresponds to charge transfer between ferric cations and adjacent oxygen anions. The strong absorption edge between 0.4 and $0.6 \mu \mathrm{m}$ is related to paired excitations between magnetically coupled ferric cations (Sherman \& Waite [21], Crowley et al. [25]), while the broad absorption bands around $0.9 \mu \mathrm{m}$ can be attributed to crystal field absorption bands in ferric $(0.75-0.95 \mu \mathrm{m})$ or ferrous $(0.9-1.1 \mu \mathrm{m})$ iron bearing minerals. Features observed around $2.20 \mu \mathrm{m}$ are attributable to the Al-O-H combination bands while those observed between 2.25 and $2.38 \mu \mathrm{m}$ are due to $\mathrm{Fe}-\mathrm{O}-\mathrm{H}$ and $\mathrm{Mg}-\mathrm{O}-\mathrm{H}$ combination bands (Crowley et al. [25], Clark [23]). Based on these observations, it is clear that the different surfaces can be discriminated from one another. The next step consists of identifying the various minerals that contribute to their composition using the wavelength position of the absorption features. Comparison with spectra of pure reference minerals was performed on "raw" spectra and after continuum removal. 


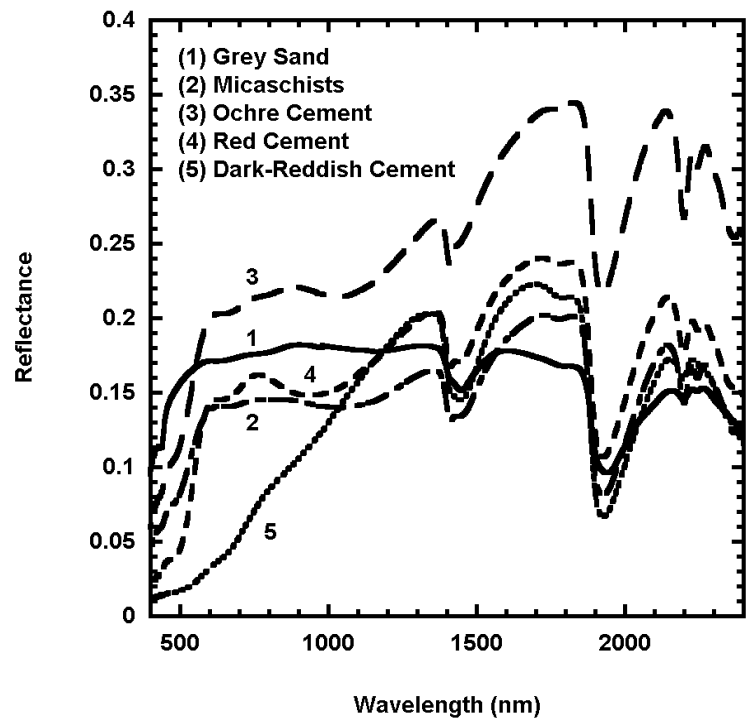

Figure 2: Reflectance spectra of typical surface types.

\subsection{Continuum removal}

The overall shape of a reflectance spectrum (or continuum) is related to physical properties of the surface (e.g. grain size, roughness, moisture content, local slope, etc.) which may change from place to place despite a homogeneous composition. In order to better identify a spectral feature by its wavelength position, it must be isolated from these other effects. The first step is continuum definition and removal. Following the definition of Clark and Roush [26], the continuum needs tie points at local maximum reflectance but there might be no stable tie points toward the blue or the infrared for natural surfaces. Therefore, the continuum can be defined in different ways: (1) using straight lines in wavelength, linking local maxima between absorption features, including starting and ending wavelength; this can be called the "straight line" approach (Figure 3A); (2) using a gaussian decomposition for the absorption features and a straight line in wavenumber for the continuum to overcome the instabilities at both end of the spectrum; this is done by the Modified Gaussian Model (MGM) developed by Sunshine et al. [27] (Figure 3B). The spectral deconvolution by MGM uses a non-linear least-squares analysis. The measured spectrum reflectance at a given wavelength is fitted by a superposition of $n$ Gaussian distributions (each is defined by three parameters: central wavelength, half-width and negative strength) and a continuum curve (slope and intercept for a straight line in wavenumber). The inversion process must start with an initial set of parameters that includes absorption band centers and full width at half maximum. These parameters are chosen by observing the spectral shapes and following a priori knowledge about spectral characteristics (Figure 3B). 
Once the continuum line is established, the continuum-removed spectra are calculated by dividing the original reflectance values by the corresponding values of the continuum line. As the tie points can be different for the various surfaces depending in their mineralogical composition, the spectra were treated globally.
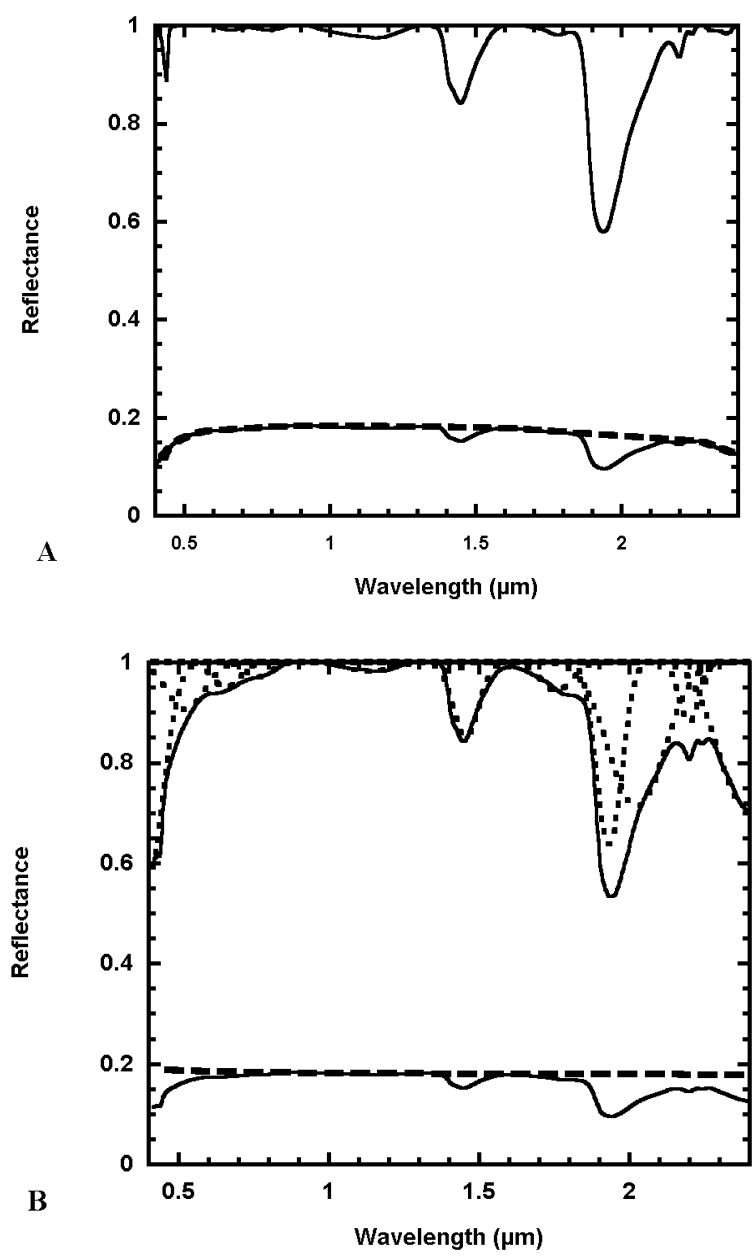

Figure 3: A - Continuum removal using the "straight line" approach; solid line: original spectrum (bottom) and after continuum removal (top), dashed line: continuum. B - Principle of the spectral modelling using the MGM; solid line: original spectrum (bottom) and after continuum removal (top), dashed line: continuum, dotted line: gaussian functions used to model the original spectrum. 


\subsection{Mineral discrimination based on spectral features}

A reference spectral database, published by Crowley et al. [25] containing the main minerals that can be encountered in sulphide-rich mine waste piles was used. Only minerals supposed to be stable in the environmental conditions of our test site (exposed settings, dry conditions), were selected for comparison. Primary ore minerals (muscovite, scheelite or dravite) were also included but not quartz or feldspar since these minerals, although present, do not show any absorption features in the wavelength range considered here. A list of reference minerals and formula is presented in Table 1 . The 1.4 and $1.9 \mu \mathrm{m}$ absorption features attributable to $\mathrm{H}_{2} \mathrm{O}$ were excluded of the identification procedure since they are present in most minerals and therefore not discriminant.

Table 1: Reference database mineral names and formula.

\begin{tabular}{|l|l|}
\hline \multicolumn{1}{|c|}{ Mineral } & \multicolumn{1}{c|}{ Formula } \\
\hline Dravite (Tourmaline) & $\mathrm{NaMg}_{3}(\mathrm{Al}, \mathrm{Fe})_{6} \mathrm{Si}_{6} \mathrm{O}_{18}\left(\mathrm{BO}_{3}\right)_{3}(\mathrm{OH})_{4}$ \\
\hline Ferrihydrite & $5 \mathrm{Fe}_{2}{ }^{3+} \mathrm{O}_{3} * 9 \mathrm{H}_{2} \mathrm{O}$ \\
\hline Fibroferrite & $\mathrm{Fe}^{3+}\left(\mathrm{SO}_{4}\right)(\mathrm{OH})^{*} 5 \mathrm{H}_{2} \mathrm{O}$ \\
\hline Goethite & $\alpha-\mathrm{Fe}^{3+} \mathrm{O}(\mathrm{OH})$ \\
\hline Hematite & $\alpha-\mathrm{Fe}_{2}{ }^{3+} \mathrm{O}_{3}$ \\
\hline Jarosite & $\mathrm{KFe}_{3}{ }^{3+}\left(\mathrm{SO}_{4}\right)_{2}(\mathrm{OH})_{6}$ \\
\hline Limonite & $\mathrm{Mixture}_{2}$ of hydrated iron oxides \\
\hline Muscovite & $\mathrm{KAl}_{2}\left(\mathrm{AlSi}_{3}\right) \mathrm{O}_{10}(\mathrm{OH})_{2}$ \\
\hline Paracoquimbite & $\mathrm{Fe}_{2}{ }^{3+}\left(\mathrm{SO}_{4}\right)_{3}{ }^{*} 9 \mathrm{H}_{2} \mathrm{O}$ \\
\hline Rozenite & $\mathrm{Fe}^{2+} \mathrm{SO}_{4}{ }^{*} 4 \mathrm{H}_{2} \mathrm{O}$ \\
\hline Scheelite & $\mathrm{CaWO}_{4}$ \\
\hline Schwertmannite & $\mathrm{Fe}_{16}{ }^{3+} \mathrm{O}_{16}(\mathrm{OH})_{12}\left(\mathrm{SO}_{4}\right)_{2}$ \\
\hline Szomolnokite & $\mathrm{Fe}^{2+} \mathrm{SO}_{4}{ }^{*} \mathrm{H}_{2} \mathrm{O}$ \\
\hline
\end{tabular}

\subsection{1 "Raw" spectra}

Precise location of absorption features is more difficult to define on raw reflectance spectra, particularly in the case of broad absorptions. In a first approximation, jarosite was identified in grey sand, micaschists and dark-reddish cement. Goethite is found in ochre and red cement, schwertmannite in micaschists and possibly in dark-reddish cement. Scheelite is present in grey sand, micaschists and ochre cement and muscovite in dark-reddish cement.

\subsection{2 "Straight line" continuum removal}

Removing the continuum helps locating more precisely the absorption positions. Results show that it is more likely that hematite rather than goethite is present, or more probably a mixture of hydrated iron oxides such as limonite, based on the position of the broad absorption feature around $0.9 \mu \mathrm{m}$. The presence of jarosite in micaschists and grey cement, and of schwertmannite in dark-reddish cement is confirmed. Dravite is clearly present in micaschists and possibly in grey sand and ochre cement. Exact match with scheelite and muscovite is difficult probably 
because of mixing effects, and of the close positions of their absorption features around $2.20 \mu \mathrm{m}$.

\subsubsection{Using MGM gaussian function positions}

Deconvolution of spectra using the MGM produces more gaussian functions than "realistic" absorption features. Therefore, it is harder to decipher the results. This technique appears also highly sensitive to input parameters which require some a priori knowledge. Several runs were necessary to adjust the parameters and reach a reasonable fit. Although the wavelength positions of the gaussian function did not exactly match the absorption positions determined in the previous steps, the presence of scheelite in grey sand and of hematite rather than goethite was confirmed. This approach requires further improvement in order to be operational on spectra of natural surfaces. A thorough sensitivity analysis of the deconvolution to input parameters is also required.

\section{SEM-EDS and XRD data}

XRD, performed on a limited number of samples due to time constraints, confirmed the presence of jarosite, dravite and muscovite in the ochre cement. Indications of quartz and chlorite or serpentine were also found but not for clays. SEM-EDS analyses were performed on minerals appearing to be statistically representative of the samples. These analyses confirmed the presence of primary ore minerals such as muscovite, quartz, feldspar and garnet as well as pyrite, ferberite or wolframite $\left[(\mathrm{Fe}, \mathrm{Mn}) \mathrm{WO}_{4}\right]$. Hydroxides, hydrated arsenates and phosphates, also present, were harder to identify since $(\mathrm{OH})$ or $\left(\mathrm{H}_{2} \mathrm{O}\right)$ quantities cannot be estimated accurately with this technique.

\section{Conclusion}

These preliminary results show that identifying specific minerals present in cements developed at the surface of tailings can be complicated. In principle, many ferric oxide and sulphate minerals should be distinguishable by using field spectral measurements, as well as existing hyperspectral sensors. In practice however the ability to discern individual iron sulphate or oxide species is limited by the occurrence of the minerals in complex mixtures with each other and with other surficial materials. Mineral mixing, grain size and mineral composition are important factors influencing the spectral signature, making direct comparison between reference and measured reflectance spectra difficult. Selecting the proper endmembers to perform spectral unmixing is rather complicated because of the different sources of changes previously mentioned. This study showed that removing the continuum improved identification as it allows one to focus on absorption wavelength positions. It might be necessary to work on specific absorptions individually to improve the results. Using the MGM technique should give access to more quantitative information such as absorption depth and area that can be related to concentration or fractional composition but this approach needs to be more thoroughly evaluated when applied to natural 
surfaces. Its sensitivity to input parameters needs to be characterized. Finally, detailed analysis of the chemical and mineralogical composition of the samples is necessary to better understand the optical properties of such surfaces.

\section{References}

[1] Johnson, C.A. \& Thornton, I., Hydrological and chemical factors controlling the concentrations of $\mathrm{Fe}, \mathrm{Cu}, \mathrm{Zn}$ and $\mathrm{As}$ in a river system contaminated by acid mine drainage. Water Res., 21, pp. 359-365, 1987.

[2] Webster, J.G., Nordstrom, D.K. \& Smith, K.S., Transport and natural attenuation of $\mathrm{Cu}, \mathrm{Zn}, \mathrm{As}$, and $\mathrm{Fe}$ in the acid mine drainage of Leviathan and Bryant Creeks, Environmental Geochemistry of Sulfide Oxidation, eds. Alpers, C.N., Blowes, D.W., Am. Chem. Soc. Symp. Series, 550, pp. 244-260, 1994.

[3] Herbert, R.B., Properties of goethite and jarosite precipitated from acidic groundwater, Dalarna, Sweden. Clays and Clay Minerals, 45, pp. 261273, 1997.

[4] Karathanasis, A.D. \& Thompson, Y.L., Mineralogy of iron precipitates in a constructed acid mine drainage wetland. Soil Sci. Soc. Am. J., 59, pp. 1773-1781, 1995.

[5] Azcue, J., Muroch, A., Rosa, F. \& Hall, G., Effects of abandoned gold mine tailings on the arsenic concentrations in water and sediments of Jack of Clubs Lake, B.C. Environ. Technol., 15, pp. 669-678, 1994.

[6] Hunt, L.E. \& Howard, A.G., Arsenic speciation and distribution in the Carnon Estuary following the acute discharge of contaminated water from a disused mine. Marine Poll. Bull., 28, pp. 33-38, 1994.

[7] Roussel, C., Bril, H. \& Fernandez A., Arsenic speciation: Involvement in evalution of environmental impact caused by mine wastes. J. Environ. Qual., 29, pp. 182-188, 2000.

[8] Richardson, S. \& Vaughan D.J., Arsenopyrite: a spectroscopic investigation of altered surfaces. Mineral. Mag. 53, pp. 223-229, 1989.

[9] Nesbitt, H.W., Muir, I.J. \& Pratt, A.R., Oxidation of arsenopyrite by air and air-saturated, distilled water, and implications for mechanism of oxidation. Geochim. Cosmochim. Acta, 59, pp. 1773-1786, 1995.

[10] Savage, K.S., Tingle, T.N., O’Day, P., Waychunas, G.A. \& Bird, D.K., Arsenic speciation in pyrite and secondary weathering phases, Mother Lode Gold District, Tuolumne County, California. Appl. Geochem., 15, pp. 1219-1244, 2000.

[11] Scott, K.M., Solid solution in, and classification of, gossan-derived members of the alunite-jarosite family, northwest Queensland, Australia. Am. Mineral., 72, pp. 178-187, 1987.

[12] Jambor, J.L., Nomenclature of the alunite supergroup. Can. Mineral, 37, pp. 1323-1341, 1999.

[13] Pierce, M. \& Moore, C., Adsorption of arsenite and arsenate on amorphous iron hydroxide. Water Res., 16, pp. 1247-1253, 1982. 
[14] Tsung-Hui, H., Shang-Lien, L., Cheng-Fang, L. \& Dar-Yuan, L., Characterization of arsenate adsorption on hydrous iron oxide using chemical and physical methods. Colloids and Surfaces A: Physiochem. Eng. Aspects, 85, pp. 1-7, 1994.

[15] Manning, B.A., Fendorf, S.E. \& Goldberg, S., Surface structures and stability of arsenic (III) on goethite: spectroscopic evidence for innersphere complexes. Environ. Sci. Technol., 32, pp. 2383-2388, 1998.

[16] Courtin-Nomade, A., Bril, H., Néel, C. \& Lenain, J.F, Arsenic in iron cements developed within tailings of a former metalliferous mine Enguialès, Aveyron, France. Applied Geochem., 18, pp. 395-408, 2003.

[17] Swayze, G.A., Smith, K.S., Clark, R.N., Sutley, S.J., Pearson, R.M., Vance, J.S., Hageman, P.L., Briggs, P.H., Meier, A.L., Singleton, M.J. \& Roth, S., Using imaging spectroscopy to map acidic mine waste. Environmental Science and Technology, 34, pp. 47-54, 2000.

[18] Courtin-Nomade, A., Néel, C., Bril H. \& Davranche, M., Trapping and mobilisation of arsenic and lead in former mine tailings - Environmental conditions effects. Bull. Soc. Geol. France, 173, pp. 479-485, 2002.

[19] Stahl, R.S., Fanning, D.S. \& James, B.R., Goethite and jarosite precipitation from ferrous sulfate solutions. Soil Sci. Soc. Am., 57, pp. 280-282, 1993.

[20] Hunt, G.R. \& Ashley R.P., Spectra of altered rocks in the visible and near infrared. Economic Geol., 74, pp. 1613-1629, 1979.

[21] Sherman, D.M. \& Waite, T.D., Electronic spectra of $\mathrm{Fe}^{3+}$ oxides and oxide hydroxides in the near IR to near UV, American Mineralogist, 70, pp. 1262-1269, 1985.

[22] Burns, R.G., Mineralogical application of crystal field theory. Cambridge University Press, Cambridge, 1993.

[23] Clark, R.N., Spectroscopy of rocks and minerals and principles of spectroscopy (Chapter 1). Manual of Remote Sensing, ed. A.N. Rencz, John Wiley and Sons, New York, pp. 3-58, 1999.

[24] Hunt, G.R., Salisbury, J.W. \& Lenhoff, C.J., Visible and near-infrared spectra of minerals and rocks: IV. Sulphides and sulphates, Modern Geol., 3, pp. 1-14, 1971.

[25] Crowley, J.K., Williams, D.E., Hammarstrom, J.M., Piatak, N., I-Ming Chou \& Mars, J.C., Spectral reflectance properties $(0.4-2.5 \mu \mathrm{m})$ of secondary Fe-oxide, Fe-hydroxide, and Fe-sulphate-hydrate minerals associated with sulphide-bearing mine wastes, Geochemistry: Exploration, Environ., Analysis, 3, pp. 219-228, 2003.

[26] Clark, R.N. \& Roush, T., Reflectance spectroscopy: quantitative analysis techniques for remote sensing applications. J. Geoph. Res., 89, pp. 63296340, 1984.

[27] Sunshine J., Pieters, C.M. \& Pratt, S.F., Deconvolution of mineral absorption bands: an improved approach, J. Geoph. Res., 93, pp. 69556966, 1990. 